\title{
Histological Characterization of Resistance to Uromyces viciae-fabae in Faba Bean
}

\author{
J. C. Sillero and D. Rubiales
}

First author: CIFA, Dep. Mejora y Agronomía, Apdo. 3092, E-14080 Córdoba, Spain; and second author: Instituto de Agricultura Sostenible, CSIC. Apdo. 4084, E-14080 Córdoba, Spain.

Accepted for publication 31 October 2001.

\section{ABSTRACT}

Sillero, J. C., and Rubiales, D. 2002. Histological characterization of resistance to Uromyces viciae-fabae in faba bean. Phytopathology 92: 294-299.

Components of resistance to the faba bean rust (Uromyces viciaefabae) were studied at the histological level in seedlings and adult plants of nine faba bean (Vicia faba) lines differing in their level of resistance. Resistance of these lines was previously shown to be characterized macroscopically by an increased latent period, a decreased colony size, and a relatively decreased infection frequency. In some lines, the resistance also was associated with macroscopically visible necrosis. Histological investigations revealed few differences in spore germination and appressorium formation. Significant levels of aborted stomatal penetra- tion by the rust fungus were found on all resistant lines. However, differences among lines were more evident once the stomata were penetrated by the infection structures. Resistance was mainly due to a restriction of haustorium formation with varying levels of early abortion of the colonies, a reduction in the number of haustoria per colony, and smaller colony size. In addition, necrosis of the host cells associated with infection hyphae was detectable in some lines from the beginning of colony development. This microscopically visible necrosis became stronger from 4 days after inoculation, resulting in a reduced growth of the colony. Differences in resistance levels were more marked in adult plants than in seedlings.

Additional keywords: hypersensitive resistance, rust, Vicia faba.
Faba bean rust, caused by Uromyces viciae-fabae (Pers.) J. Schröt., is a disease of worldwide distribution. It is of major importance in the Middle East and North Africa, where moderate to substantial yield losses can occur $(14,24)$, particularly if the disease starts early in the season.

Several Vicia faba sources of incomplete resistance to $U$. viciae-fabae have been reported. In these sources, resistance is expressed as a reduction of disease severity without any macroscopically visible necrosis $(1,5,11,22-24,31)$. Hypersensitive resistance to faba bean rust only recently has been described. This form of incomplete hypersensitive resistance is associated with late-acting necrosis of the host tissue resulting in a reduction of the infection type (31). Both types of incomplete resistance are associated with an increased latent period, a reduction in colony size $(3,23,31)$, and a decreased infection frequency (2). They only differ in the presence or absence of macroscopically visible necrosis (31).

Different resistance mechanisms may be operative at different phases of the infection process, from spore deposition, spore germination, germ tube orientation, appressorium formation, stoma penetration, and infection hyphae growth rate, to percentage of successful haustoria formation. In most rust pathosystems, spore germination and appressorium formation are independent of the host plant genotype (7), but once the appressorium and the substomatal vesicle have been successfully formed, plant genotypes differ in the extent to which pre- and posthaustorial mechanisms of resistance are operating $(8,10,19,30)$. The purpose of this study was to identify histologically the defense reactions to faba bean rust in seedlings and adult plants of the faba bean lines displaying incomplete nonhypersensitive and hypersensitive resistance.

Corresponding author: D. Rubiales; E-mail address: ge2ruozd@uco.es

Publication no. P-2002-0102-01R

(c) 2002 The American Phytopathological Society

\section{MATERIALS AND METHODS}

Nine faba bean genotypes differing in the level of resistance under field or controlled conditions (31) were selected for the study of the cellular responses to infection by faba bean rust. Lines V-300, V-1271, V-1273, and 2N-34 were selected on the basis of a low infection type (IT). BPL-261, which displays a high IT, was selected on the basis of its reduced disease severity (DS) and prolonged latent period (LP). Lines VF-16, VF-40, L82009, and BPL-484 showed some degree of reduction of the DS in the field. The line VF-176 was included as a susceptible check.

Seedling and adult plant experiments were carried out in a growth chamber. Three consecutive series were performed for seedlings and adult plants separately, each one consisting of six replications per genotype. In seedling experiments, plants were grown in plastic boxes ( 35 by 35 by $10 \mathrm{~cm}$ ) filled with a $1: 1 \mathrm{mix}-$ ture of sand and peat. Each series consisted of three boxes with two seedlings per genotype each. In adult plant experiments, plants were sown in 2-liter plastic pots.

Single spore isolate 96-Cord-2 of $U$. viciae-fabae was used in all experiments. Inoculum was produced on plants of the susceptible line VF-176 and collected $24 \mathrm{~h}$ before inoculation. Seedlings were inoculated when the second leaf was completely expanded. Leaves were pinned to soil in a horizontal position and the adaxial surface of the leaves was inoculated in a spore settling tower by dusting $2 \mathrm{mg}$ of spores per plant, diluted in pure talc (1:10), resulting in a spore deposition of 20 spores per $\mathrm{mm}^{2}$. In each of the three consecutive series, inoculation were performed in three runs, each one including a box with two seedlings per genotype. In the adult plant experiment, the 10th to 12th fully expanded leaves were inoculated in a spore settling tower in six runs, each one including a pot of each genotype, by dusting with $5 \mathrm{mg}$ of spores per plant diluted in pure talc (1:10). Plants were incubated for $24 \mathrm{~h}$ at $20^{\circ} \mathrm{C}$ in complete darkness and $100 \%$ relative humidity, then 
transferred to a growth chamber at $20^{\circ} \mathrm{C}$ under a photoperiod of 14-h light and 10-h dark with light intensity of $148 \mu \mathrm{mol} / \mathrm{m}^{2} / \mathrm{s}$ at the leaf canopy.

Leaf segments of 2 to $3 \mathrm{~cm}^{2}$ were collected 2 days after inoculation (DAI) and processed to study the phases of the fungus growth prior to stoma penetration (27). Three leaf samples per genotype per replication were cut. The leaf samples were laid, adaxial surface up, on filter paper dipped on fixative $(1: 1$, absolute ethanol/glacial acetic acid, vol/vol). When the leaf segments were bleached by several changes of the fixative, they were transferred to filter paper moistened with tap water for at least $2 \mathrm{~h}$ to soften the tissues. Next, they were transferred to lactoglycerol (1:1:1, lactic acid/glycerol/water, vol/vol/vol) for at least $2 \mathrm{~h}$. To stain the samples, a drop of Trypan blue in lactoglycerol $(0.1 \%$, wt $/ \mathrm{vol})$ was placed on a cover glass and the sample was carefully laid with the adaxial surface to the cover, then mounted in lactoglycerol on a microscope slide. Urediospores $(\approx 125$ per leaf sample) were counted under $\times 200$ magnification with a Leica DM LS microscope and grouped into the following categories: germinated urediospores (a spore was considered germinated when a germ tube at least as long as the diameter of the spore has been produced); germ tubes growing over stomata but not forming appressoria; and germ tubes forming appressoria. Of the germ tubes forming appressoria, distinction was made whether the appressorium was formed over a stoma or away from the stoma (misplaced) and, of those formed over a stoma, distinction was made whether or not stomata were penetrated (a substomatal vesicle [SSV] formed inside of the stoma).

Three further leaf samples (2 to $3 \mathrm{~cm}^{2}$ ) per genotype per replication were cut 2 DAI and stained with Trypan blue, following with slight modifications the procedure of Niks (19). The leaf segments were fixed in acetic acid/ethanol (1:3, vol/vol) for $30 \mathrm{~min}$; stained by boiling in $0.05 \%$ Trypan blue in lactophenol/ethanol $(1: 2, \mathrm{vol} / \mathrm{vol})$ for $10 \mathrm{~min}$, and cleared in a nearly saturated aqueous solution of chloral hydrate $(5: 2, \mathrm{wt} / \mathrm{vol})$ to remove Trypan blue from the chloroplast membranes. Early stages of the infection were studied microscopically, using a phase contrast Leica DM LS microscope at $\times 400$ magnification. Per leaf piece, 15 to 20 random colonies were studied. Of each colony, number of hyphal tips and haustoria were counted. Also, presence or absence of necrosis of the host cells associated to an infection structure was recorded. Necrosis was identified by uptake of Trypan blue by the plant cells.

At 4, 6, and 8 DAI, three additional 2- to $3-\mathrm{cm}^{2}$ leaf samples per line and replication were cut and stained with Uvitex $2 \mathrm{~B}$ according to the method of Rohringer et al. (25), but boiled in saturated chloral hydrate $(5: 2, \mathrm{wt} / \mathrm{vol})$, instead of in lactophenol/ethanol, to clarify the leaf tissues. The colony size (CS) was measured using a Leica DM LB epifluorescence microscope at $\times 100$ (those cut at
6 and 8 DAI) or $\times 200$ (those cut at 4 DAI) magnification, with an excitation filter of 380 to $425 \mathrm{~nm}$. The length (L) and width (W) of 25 randomly chosen established colonies per leaf piece were measured with an eyepiece micrometer. CS was calculated using the formula: $\mathrm{CS}=1 / 4 \pi \mathrm{LW}$. Values for areas were transformed to square roots to obtain a linear rather than a quadratic value for colony area (19). The means of the observed values of CS were converted into relative values per experiment (seedlings or adult plants) and expressed as percentage of the susceptible check, VF$176(=100 \%)$. The presence of host cell necrosis associated with the rust colonies was identified by the golden yellow autofluorescence displayed when changing the excitation filter of the microscope (420 to $490 \mathrm{~nm}$ ). The presence of sporogenic tissue or sporulation in the colonies was also determined.

IT was scored 10 to $15 \mathrm{DAI}$ on remaining leaves using the IT scale of Stakman et al. (32), where $0=$ no symptoms, $;=$ necrotic flecks, $1=$ minute pustules barely sporulating, $2=$ necrotic halo surrounding small pustules, $3=$ chlorotic halo, and $4=$ wellformed pustules with no associated chlorosis or necrosis.

Comparison of means (Duncan test, $P<0.05$ ) was made for all microscopical components of resistance among faba bean lines. When the components of resistance were expressed as percentage, data were angular transformed prior to an analysis of variance. Pearson's linear correlation coefficient between macroscopical components of resistance (31) and histological parameters were calculated. Statistical analyses were performed using SAS (version 6.03; SAS Institute Inc., Cary, NC).

\section{RESULTS}

For most infection stages before stoma penetration, there were no or only small significant differences between the lines (Table 1). The only aspect in which the rust fungus was clearly more successful on the susceptible check VF-176 than on all other lines was stoma penetration. On VF-176, more appressoria penetrated the stoma successfully (74\%) (Table 1) than on the other lines (46 to $60 \%$ ). Appressoria that failed to penetrate a stoma had either formed an SSV before entering the stoma or failed to form an SSV at all. The proportion of appressoria formed over stomata but developing a substomatal vesicle outside of the stoma was significantly higher in lines V-300 (24.5\%) and V-1271 (36\%) than in the check $(13.3 \%)$.

Differences in the development of the infection process among resistant and susceptible lines in seedlings were evident 2 DAI. (Table 2). There was a relatively small proportion of infection units on some of the lines that had failed to form any haustoria and hence aborted early. Significant differences among lines were found for the percentage of early aborted infection units. Very few infection units $(\leq 7 \%)$ were associated with host cell necrosis.

TABLE 1. Percentage of events in the early development of infection units of Uromyces viciae-fabae on seedlings of faba bean lines ${ }^{t}$

\begin{tabular}{|c|c|c|c|c|c|c|c|}
\hline \multirow[b]{2}{*}{ Line } & \multirow[b]{2}{*}{ Spore germination $(\%)$} & \multicolumn{3}{|c|}{ Germ tubes $(\%)$} & \multicolumn{3}{|c|}{ Appressoria (\%) } \\
\hline & & No appressorium $^{\mathrm{u}}$ & Misplaced appressorium $^{v}$ & Over stoma $^{w}$ & Penetrated stoma $^{\mathrm{x}}$ & SSV outside stoma ${ }^{\mathrm{y}}$ & No SSVz \\
\hline VF-176 & $86.4 \mathrm{ab}$ & $58.8 \mathrm{ab}$ & $22.0 \mathrm{a}$ & $19.2 \mathrm{~b}$ & $74.4 \mathrm{a}$ & $13.3 \mathrm{c}$ & $12.3 \mathrm{~b}$ \\
\hline VF-16 & $86.9 \mathrm{ab}$ & $62.2 \mathrm{a}$ & $20.9 \mathrm{a}$ & $17.0 \mathrm{~b}$ & $59.7 \mathrm{~b}$ & $19.6 \mathrm{bc}$ & $20.7 \mathrm{ab}$ \\
\hline VF-40 & $88.5 \mathrm{a}$ & $59.8 \mathrm{ab}$ & $20.3 \mathrm{a}$ & $19.9 \mathrm{~b}$ & $57.5 \mathrm{~b}$ & $19.5 \mathrm{bc}$ & $22.9 \mathrm{ab}$ \\
\hline BPL-261 & $88.9 \mathrm{a}$ & $63.5 \mathrm{a}$ & $19.2 \mathrm{a}$ & $17.3 \mathrm{~b}$ & $57.3 \mathrm{~b}$ & $17.2 \mathrm{bc}$ & $25.5 \mathrm{a}$ \\
\hline $2 \mathrm{~N}-34$ & $85.1 \mathrm{ab}$ & $62.1 \mathrm{a}$ & $21.2 \mathrm{a}$ & $16.6 \mathrm{~b}$ & $56.8 \mathrm{~b}$ & $21.8 \mathrm{bc}$ & $21.4 \mathrm{ab}$ \\
\hline V-300 & $85.4 \mathrm{ab}$ & $60.5 \mathrm{ab}$ & $20.2 \mathrm{a}$ & $19.3 \mathrm{~b}$ & $54.9 \mathrm{bc}$ & $24.5 \mathrm{ab}$ & $20.3 \mathrm{ab}$ \\
\hline V-1271 & $83.6 \mathrm{~b}$ & $52.6 \mathrm{c}$ & $20.1 \mathrm{a}$ & $27.3 \mathrm{a}$ & $46.0 \mathrm{c}$ & $36.0 \mathrm{a}$ & $18.0 \mathrm{ab}$ \\
\hline V-1273 & $87.3 \mathrm{ab}$ & $55.8 \mathrm{bc}$ & $18.0 \mathrm{a}$ & $26.2 \mathrm{a}$ & $60.0 \mathrm{~b}$ & $21.5 \mathrm{bc}$ & $18.5 \mathrm{ab}$ \\
\hline
\end{tabular}

t Values with letter in common in each column are not significantly different $(P<0.05$, Duncan test).

" Germ tubes not forming appressorium.

v Germ tubes forming a misplaced appressorium (away from the stoma).

${ }^{\mathrm{w}}$ Germ tubes forming an appressorium over a stoma.

x Appressoria formed over stomata that successfully penetrated the stoma.

y Appressoria formed over stomata that formed a substomatal vesicle (SSV) but outside the stoma.

${ }^{\mathrm{z}}$ Appressoria formed over stomata that did not form a SSV at all. 
However, this proportion was significantly higher in some of the lines than in the check. Necrotic cells were visible as a darkening of the cell contents to such an extent that usually it was impossible to determine the presence of a haustorium. Differences also were found among lines in the rate of haustoria formation. Significantly fewer haustoria were formed in lines V-300, V-1271, 2N34, BPL-261, VF-16, and VF-40 than in the check. Intercellular growth of the colonies was reduced in some of the lines. The number of hyphal tips per colony was significantly lower in line $\mathrm{V}-300$ than in the check.

In adult plants, the percentage of early aborted infection units, not forming any haustoria, was higher (maximum $48.7 \%$ ) than in

TABLE 2. Early stages of the infection of in resistant and susceptible faba bean lines by Uromyces viciae-fabae and final infection type ${ }^{\mathrm{z}}$

\begin{tabular}{llcccc}
\hline Line & $\begin{array}{c}\text { Infection } \\
\text { type }\end{array}$ & $\begin{array}{c}\text { Early } \\
\text { abortion } \\
(\%)\end{array}$ & $\begin{array}{c}\text { Colonies with } \\
\text { necrosis }(\%)\end{array}$ & $\begin{array}{c}\text { No. of } \\
\text { haustoria/ } \\
\text { colony }\end{array}$ & $\begin{array}{c}\text { No. of } \\
\text { hyphal } \\
\text { tips/colony }\end{array}$ \\
\hline Seedling & & & & & \\
VF-176 & 4 & $0.6 \mathrm{~b}$ & $0.0 \mathrm{~h}$ & $3.5 \mathrm{a}$ & $8.3 \mathrm{ab}$ \\
BPL-484 & 4 & $0.2 \mathrm{~b}$ & $0.0 \mathrm{~h}$ & $3.3 \mathrm{a}$ & $9.3 \mathrm{a}$ \\
VF-16 & 4 & $4.4 \mathrm{ab}$ & $0.1 \mathrm{~g}$ & $2.6 \mathrm{~b}$ & $8.6 \mathrm{ab}$ \\
VF-40 & 4 & $12.2 \mathrm{a}$ & $0.3 \mathrm{f}$ & $2.1 \mathrm{bc}$ & $7.7 \mathrm{a}-\mathrm{c}$ \\
L82009 & 4 & $4.4 \mathrm{ab}$ & $0.0 \mathrm{~h}$ & $2.8 \mathrm{ab}$ & $7.5 \mathrm{bc}$ \\
BPL-261 & 4 & $16.3 \mathrm{a}$ & $2.5 \mathrm{e}$ & $1.8 \mathrm{c}$ & $7.4 \mathrm{bc}$ \\
2N-34 & $;-2+$ & $10.5 \mathrm{a}$ & $4.8 \mathrm{~b}$ & $2.5 \mathrm{bc}$ & $7.5 \mathrm{bc}$ \\
V-1271 & $2-2+$ & $12.8 \mathrm{a}$ & $7.0 \mathrm{a}$ & $2.4 \mathrm{bc}$ & $7.9 \mathrm{a}-\mathrm{c}$ \\
V-1273 & $2-2+$ & $12.2 \mathrm{a}$ & $3.8 \mathrm{~d}$ & $2.7 \mathrm{ab}$ & $8.4 \mathrm{ab}$ \\
V-300 & $2+$ & $12.1 \mathrm{a}$ & $4.2 \mathrm{c}$ & $2.2 \mathrm{bc}$ & $7.3 \mathrm{c}$ \\
Adult plant & & & & & \\
VF-176 & 4 & $1.6 \mathrm{de}$ & $0.0 \mathrm{c}$ & $2.3 \mathrm{a}$ & $6.2 \mathrm{a}$ \\
BPL-484 & 4 & $0.1 \mathrm{e}$ & $0.0 \mathrm{c}$ & $2.1 \mathrm{a}$ & $5.7 \mathrm{a}$ \\
VF-16 & 4 & $11.9 \mathrm{c}-\mathrm{e}$ & $0.0 \mathrm{c}$ & $2.0 \mathrm{a}$ & $6.5 \mathrm{a}$ \\
VF-40 & 4 & $38.0 \mathrm{ab}$ & $0.1 \mathrm{c}$ & $2.0 \mathrm{a}$ & $5.7 \mathrm{a}$ \\
L82009 & 4 & $31.0 \mathrm{a}-\mathrm{c}$ & $0.0 \mathrm{c}$ & $1.8 \mathrm{a}$ & $4.9 \mathrm{a}$ \\
BPL-261 & 4 & $35.4 \mathrm{ab}$ & $1.2 \mathrm{c}$ & $1.6 \mathrm{ab}$ & $6.3 \mathrm{a}$ \\
2N-34 & $;-2$ & $23.5 \mathrm{a}-\mathrm{c}$ & $5.2 \mathrm{ab}$ & $1.7 \mathrm{ab}$ & $7.0 \mathrm{a}$ \\
V-1271 & $;-2$ & $48.7 \mathrm{a}$ & $13.0 \mathrm{a}$ & $1.6 \mathrm{ab}$ & $4.7 \mathrm{a}$ \\
V-1273 & $;-2$ & $12.2 \mathrm{~b}-\mathrm{d}$ & $10.8 \mathrm{a}$ & $0.5 \mathrm{~b}$ & $5.5 \mathrm{a}$ \\
V-300 & 2 & $20.0 \mathrm{a}-\mathrm{c}$ & $3.9 \mathrm{~b}$ & $1.5 \mathrm{ab}$ & $5.8 \mathrm{a}$ \\
\hline
\end{tabular}

z Early stage determined 2 days after inoculation (DAI); infection type determined 10 to 15 DAI according to 0-to-4 scale of Stakman et al. (32). Values with letter in common in each column and plant maturity stage are not significantly different $(P<0.05$, Duncan test $)$. seedlings (maximum 12.8\%) (Table 2) and varied significantly among lines. Early abortion was significantly higher on the lines 2N-34, V-300, V-1271, BPL-261, VF-40, and L82009 than on the check. Also, the proportion of infection units associated with host cell necrosis was higher than in seedlings, being evident for all lines displaying low IT (V-1273, V-1271, 2N-34, and V-300). The number of hyphal tips per colony was lower than in seedlings in all the lines, with little differences among lines. Also, the number of haustoria per colony was lower than in seedlings and only the line V-1273 was significantly different from the check.

Differences in CS among lines were evident 4 DAI, both at seedling and adult plant stages, and increased with time, being highest at 8 DAI (Table 3). In general, established colonies associated with plant cell necrosis were smaller than colonies not associated with such necrosis. At both plant stages, the smallest colonies were those of the lines with low IT (V-1273, V-1271, $2 \mathrm{~N}-34$, and V-300) at 4, 6, and 8 DAI. However, established colonies in line BPL-261, containing incomplete nonhypersensitive resistance, were smaller than those in the susceptible check, despite the fact that they were not associated with any cell necrosis. The colonies of lines BPL-484 and VF-40 were significantly smaller than those of the check only at $8 \mathrm{DAI}$ in adult plants. The rest of the lines did not differ from the susceptible check at both plant stages. The colonies were slightly smaller in adult plants than in seedlings at 4 and 6 DAI. This difference was much stronger at 8 DAI, but the ranking among lines was consistent. The CS increased at a similar rate in seedlings as in adult plants from 4 to $6 \mathrm{DAI}$; however, from $6 \mathrm{DAI}$, the speed of colony development was reduced in adult plants compared with that in seedlings.

The most remarkable difference among resistant lines was the presence or absence of host cell necrosis associated with the established colonies (Tables 2 and 4). This was high in the lines displaying low IT (2N-34, V-1271, V-1273, and V-300), lower in BPL-261, and negligible in the rest of the lines. Low percentages of established colonies associated with host cell necrosis were recorded 2 DAI. Some of the lines, however, differed significantly (Table 2). Presence of host cell necrosis in seedlings remained low 4 DAI (Table 4), but increased markedly in the lines with low IT from 6 DAI (range 28 to $61 \%$ ) to 8 DAI (range 62 to $75 \%$ ). Over time, necrosis was more evident in adult plants, but final ratings were lower than in seedlings.

TABLE 3. Changes in Uromyces viciae-fabae colony size at seedling and adult plant stages, 4,6 , and 8 days after inoculation (DAI) ${ }^{\mathrm{z}}$

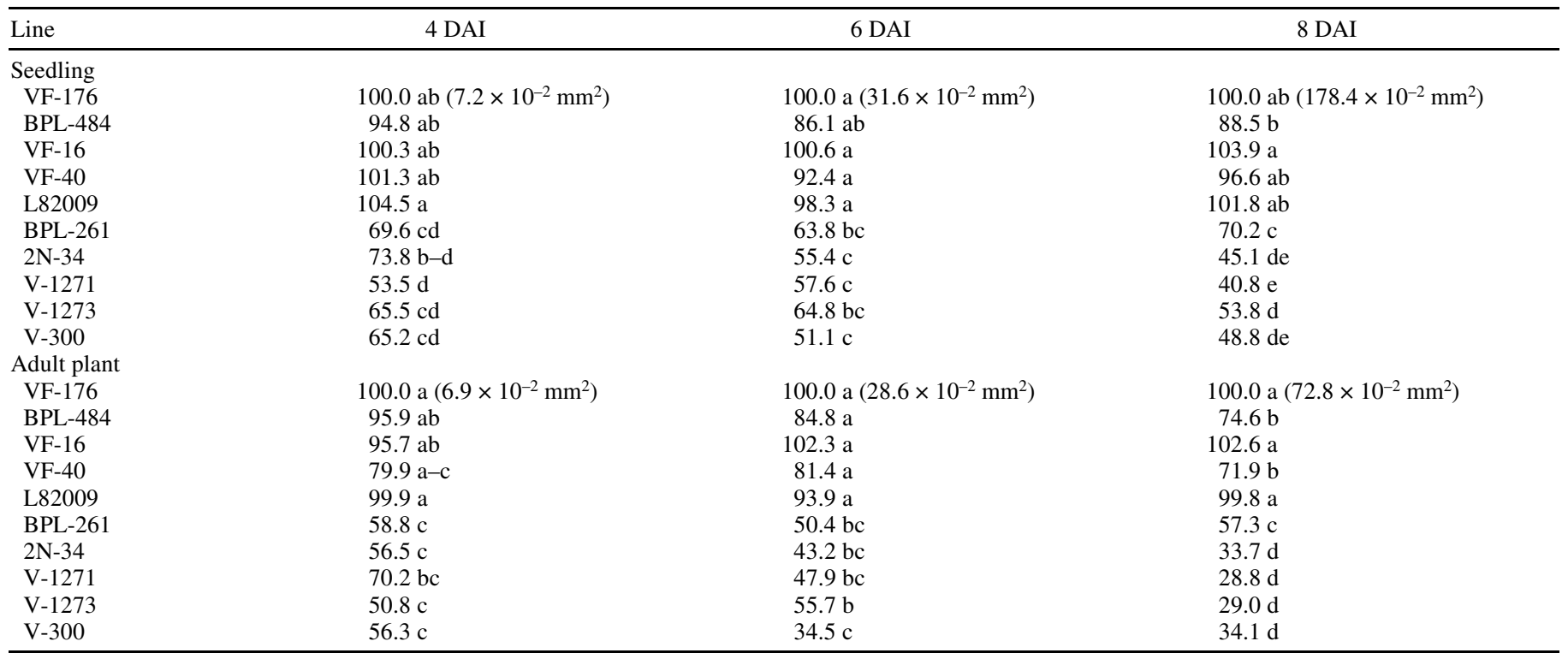

${ }^{\mathrm{z}}$ Data expressed as percentage of the susceptible check, VF-176 (=100\%); real data presented in brackets. Values with letter in common in each column and plant maturity stage are not significantly different $(P<0.05$, Duncan test). 
Sporogenic tissue was not detectable in colonies in any of the lines at 4 DAI (data not shown) but was frequent in seedlings at 6 DAI (Table 5). Excepting BPL-484 and VF-16, this proportion was strongly reduced in most of the lines. Formation of sporogenic tissue was delayed in adult plants. Sporogenic tissue was less frequently encountered in lines with low IT and in line BPL-261.

Sporulation was negligible by 6 DAI (data not shown) but frequent (95\% of colonies) at 8 DAI (Table 5) in seedlings and slightly retarded in adult plants (70\% of colonies). In seedlings, all the lines displaying low IT and the line BPL-261 allowed lower percentages of colonies to sporulate than the check. Few sporulating colonies occurred on adult plants of low IT lines and lines BPL-261 and BPL-484.

\section{DISCUSSION}

Resistance to faba bean rust is mainly of an incomplete nonhypersensitive nature, expressed by an increase of LP and decrease of CS, resulting in a reduction of disease severity in the field. Only recently we found, after an extensive search, incomplete hypersensitivity resistance resulting in late macroscopically visible necrosis (31). This resistance has not yet been extensively applied in faba bean breeding programs. Likewise, in other legume-rust pathosystems, quantitative nonhypersensitive types of resistance are predominant (e.g., in pea-U. viciae-fabae [21], chickpea-U. ciceris-arietini [28], and groundnut-Puccinia arachidis [34]). Similar to faba bean rust (31), the detection of groundnut genotypes with a delayed hypersensitive reaction is uncommon (34). In other legume-rust pathosystems (e.g., common bean- $U$. appendiculatus), hypersensitive resistance is widespread (33).

Some mechanisms of rust exclusion may occur prior to stomatal penetration by Uromyces spp. Such defense mechanisms are due to poor germling adhesion to the leaf surface $(17,37)$, deviating micromorphology of the epidermal surface that serves as cues in guiding the thigmosensing germ tube toward stomata (37), stomatal guard cell morphology (36), and leaf pubescence (18). The little varietal differences in germination, orientation, and appressorium formation presented here support the general view that reduction of urediospore germination and fungal development on

TABLE 4. Percentage of Uromyces viciae-fabae colonies associated with host cell necrosis at seedling and adult plant stages, 4, 6, and 8 days after inoculation $(\mathrm{DAI})^{\mathrm{z}}$

\begin{tabular}{|c|c|c|c|}
\hline Line & 4 DAI & $6 \mathrm{DAI}$ & 8 DAI \\
\hline \multicolumn{4}{|l|}{ Seedling } \\
\hline VF-176 & $0.1 \mathrm{~d}$ & $0.0 \mathrm{~d}$ & $0.0 \mathrm{~b}$ \\
\hline BPL-484 & $0.0 \mathrm{~d}$ & $0.0 \mathrm{~d}$ & $0.0 \mathrm{~b}$ \\
\hline VF-16 & $0.7 \mathrm{~cd}$ & $0.2 \mathrm{~d}$ & $0.2 \mathrm{~b}$ \\
\hline VF-40 & $0.6 \mathrm{~cd}$ & $0.3 \mathrm{~d}$ & $0.2 \mathrm{~b}$ \\
\hline L82009 & $0.0 \mathrm{~d}$ & $0.0 \mathrm{~d}$ & $0.0 \mathrm{~b}$ \\
\hline BPL-261 & $2.8 \mathrm{~b}-\mathrm{d}$ & $3.6 \mathrm{~d}$ & $12.8 \mathrm{~b}$ \\
\hline $2 \mathrm{~N}-34$ & $17.5 \mathrm{a}$ & $49.1 \mathrm{ab}$ & $67.0 \mathrm{a}$ \\
\hline V-1271 & $8.5 \mathrm{a}-\mathrm{c}$ & $61.5 \mathrm{a}$ & $75.6 \mathrm{a}$ \\
\hline V-1273 & $11.1 \mathrm{ab}$ & $41.2 \mathrm{bc}$ & $72.2 \mathrm{a}$ \\
\hline V-300 & $10.9 \mathrm{a}-\mathrm{c}$ & $28.6 \mathrm{c}$ & $62.7 \mathrm{a}$ \\
\hline \multicolumn{4}{|l|}{ Adult plant } \\
\hline VF-176 & $0.2 \mathrm{~b}$ & $0.0 \mathrm{~b}$ & $0.1 \mathrm{~d}$ \\
\hline BPL-484 & $0.3 \mathrm{~b}$ & $0.0 \mathrm{~b}$ & $0.0 \mathrm{~d}$ \\
\hline VF-16 & $0.0 \mathrm{~b}$ & $0.2 \mathrm{~b}$ & $0.6 \mathrm{~cd}$ \\
\hline VF-40 & $0.1 \mathrm{~b}$ & $0.0 \mathrm{~b}$ & $0.1 \mathrm{~d}$ \\
\hline L82009 & $0.1 \mathrm{~b}$ & $0.0 \mathrm{~b}$ & $0.2 \mathrm{~d}$ \\
\hline BPL-261 & $2.0 \mathrm{~b}$ & $2.6 \mathrm{~b}$ & $8.8 \mathrm{~cd}$ \\
\hline $2 \mathrm{~N}-34$ & $8.2 \mathrm{a}$ & $17.5 \mathrm{a}$ & $45.7 \mathrm{a}$ \\
\hline V-1271 & $14.6 \mathrm{~b}$ & $17.1 \mathrm{a}$ & $37.1 \mathrm{ab}$ \\
\hline V-1273 & $13.6 \mathrm{a}$ & $24.3 \mathrm{a}$ & $53.8 \mathrm{a}$ \\
\hline V-300 & $7.4 \mathrm{a}$ & $10.2 \mathrm{a}$ & $23.7 \mathrm{bc}$ \\
\hline
\end{tabular}

$\mathrm{z}$ Values with letter in common in each column and plant maturity stage are not significantly different $(P<0.05$, Duncan test). the leaf surface are, at most, of marginal importance in reducing infection levels within host species $(7,29)$. Urediospores usually germinate equally well on hosts and nonhosts, although irregular germination may occur on a few nonhosts (7). Varietal resistance due to reduction or inhibition of spore germination in a pathosystem is rare, but there are reports of slight differences in germination of urediospores of the soybean rust (Phakopsora pachyrhizi) on soybean cultivars (16) and of groundnut rust (Puccinia arachydis) on groundnut (4).

We found little difference among lines in stomatal recognition. There is evidence that urediospore germlings of bean rust ( $U$. appendiculatus) sense morphological features of host stomata over which they develop appressoria (36). Additional appressoriuminducing features have been reported on some nonhosts, resulting in high proportion of appressorium formation away from stomata. A proportion of substomatal vesicles formed "by mistake" on leaf surfaces has been commonly reported on both host and nonhosts (7) but, to our knowledge, this is the first report of differences between cultivars. There are some reports of significant genotypic effects on the stomata penetration by rust fungi $(6,12,26,35)$; however, in most studies, abortive stomata penetration has been considered irrelevant $(9,13,15,20)$. We found that successful penetration of the stoma was significantly hindered in all the resistant lines studied.

Once the fungus has successfully penetrated the stoma, microscopical differences among resistant and susceptible seedlings were evident at 2 DAI. These differences increased with time. A proportion of infection units had failed to form any haustoria in certain lines. They are considered "early aborted colonies." The frequency of these colonies was low in seedlings but considerably higher in mature plants. The fact that the number of hyphal tips per colony was similar among lines suggests that the resistance is not based on a reduction in the intercellular growth of infection hyphae, as has been suggested in the resistance of Lr34 to wheat leaf rust (30), but that either the haustorial mother cells are formed but are not functional, or that they have a reduced chance to successfully develop a haustorium in the plant cell (prehaustorial resistance). A high proportion of early aborted colonies was observed at the adult plant stage in some of the nonhypersensitive lines (BPL-261, VF-40, and L82009) but also in some of the hy-

TABLE 5. Percentage of colonies of Uromyces viciae-fabae with sporogenic tissue at 6 days after inoculation (DAI) and with sporulation at $8 \mathrm{DAI}^{\mathrm{z}}$

\begin{tabular}{lcc}
\hline & \multicolumn{2}{c}{ Colonies $(\%)$} \\
\cline { 2 - 3 } Line & With sporogenic tissue & With sporulation \\
\hline Seedling & $96.1 \mathrm{a}$ & \\
VF-176 & $95.3 \mathrm{a}$ & $95.3 \mathrm{a}$ \\
BPL-484 & $88.5 \mathrm{a}$ & $94.3 \mathrm{a}$ \\
VF-16 & $52.4 \mathrm{~b}$ & $91.3 \mathrm{a}$ \\
VF-40 & $51.3 \mathrm{~b}$ & $85.3 \mathrm{a}$ \\
L82009 & $43.7 \mathrm{bc}$ & $92.0 \mathrm{a}$ \\
BPL-261 & $34.3 \mathrm{c}$ & $45.3 \mathrm{~b}$ \\
2N-34 & $32.2 \mathrm{c}$ & $20.0 \mathrm{~b}$ \\
V-1271 & $28.6 \mathrm{c}$ & $40.7 \mathrm{~b}$ \\
V-1273 & $41.2 \mathrm{bc}$ & $36.0 \mathrm{~b}$ \\
V-300 & & $44.3 \mathrm{~b}$ \\
Adult plant & $51.1 \mathrm{a}$ & \\
VF-176 & $56.8 \mathrm{a}$ & $69.8 \mathrm{~b}$ \\
BPL-484 & $45.2 \mathrm{ab}$ & $44.5 \mathrm{c}$ \\
VF-16 & $43.6 \mathrm{ab}$ & $85.3 \mathrm{a}$ \\
VF-40 & $42.5 \mathrm{ab}$ & $78.9 \mathrm{ab}$ \\
L82009 & $17.9 \mathrm{~b}$ & $82.7 \mathrm{ab}$ \\
BPL-261 & $2.4 \mathrm{~b}$ & $22.2 \mathrm{~d}$ \\
2N-34 & $4.7 \mathrm{~b}$ & $0.8 \mathrm{e}$ \\
V-1271 & $11.5 \mathrm{~b}$ & $1.4 \mathrm{e}$ \\
V-1273 & $1.0 \mathrm{~b}$ & $0.2 \mathrm{e}$ \\
V-300 & & $0.6 \mathrm{e}$ \\
\hline Data & &
\end{tabular}

${ }_{\mathrm{z}}$ Data with the same letter per column and plant maturity stage are not significantly different $(P<0.05$, Duncan test $)$. 
persensitive lines (2N-34, V-300, and V-1271). This prehaustorial resistance is not associated with host cell necrosis, and might be responsible for most of the reduced infection frequency found in these genotypes (31), as it is suggested by the negative correlation between the early aborted colonies and the infection frequency. This is in agreement with the findings of Niks (19) in barley with partial resistance to Puccinia hordei and in flax with partial resistance to Melampsora lini (13).

When an infection unit has successfully formed a first haustorium, subsequent attempts may fail, hampering the growth of the colony. This was seen as a reduced number of haustoria per colony 2 DAI, and a subsequent delayed growth of the colony resulting in a prolonged LP and reduced CS, as described before (31). Similar to results in wheat lines with partial resistance to the wheat leaf rust (30), slow rusting line BPL-261 allowed fewer haustoria to be formed per colony than the check. All lines displaying late-acting hypersensitivity allowed formation of fewer haustoria per colony than the check by 2 DAI, when hypersensitivity was still a rather rare event. This suggests that prehaustorial resistance is also important in these lines, not only by the initial arrest of infection by early abortion, but also by continuous retardation of the colony growth by hampering subsequent haustorium formation. Slow rusting lines showed some levels of this reduction, although not always significant. Not only were the colonies smaller, but they were slower in developing sporogenic tissue and sporulation. This was particularly evident in the adult plants of the lines displaying hypersensitivity.

Host cell necrosis was relatively rare at the beginning of the infection; therefore, death of cells associated with established colonies may have moderate to little effect in reducing IF and contribute, instead, to limiting the growth of the colonies. In fact, it was common to find colonies surrounded by necrotic host cells that had not sporulated yet at 8 DAI. Therefore, this late-acting hypersensitivity results in a moderate reduction in IT and IF but in a higher increase in LP and greater reduction in CS (31) than in the nonhypersensitive lines. This was more evident in adult plants, when the growing of some colonies was completely stopped and only necrotic flecks were macroscopically observed. The contribution of the hypersensitivity in reducing CS is evidenced by the fact that differences in colony growth between lines displaying and not displaying hypersensitivity are bigger from day 6 onward, when hypersensitivity is more frequent. The continuous retardation in CS found here is similar to that observed by Herath et al. (8) in detached $V$. faba leaves, and the reduction in colony growth of $P$. recondita in partially resistant wheat (10) and of $P$. hordei in partially resistant barley (19). The decreased CSs in the resistant lines should be the responsible of the increased LP in these lines (31), as it is reflected by the negative correlation observed between the LP and the CS at any day after the inoculation.

The resistance of all the lines is incomplete. The resistance of some of the lines should be regarded as incomplete nonhypersensitive resistance (BPL-261, BPL-484, VF-40, L82009, and VF-16), and that of the others as incomplete hypersensitive resistance (V$300, \mathrm{~V}-1271, \mathrm{~V}-1273$, and $2 \mathrm{~N}-34$ ), as concluded from their phenotypes. The hypersensitivity described here is late acting, as it is hardly evident 2 DAI but strong from 6 DAI. The resistance observed in the lines VF-16, VF-40, and L82009 under field conditions is based on a reduction in the disease severity (31), which is associated with a slight reduction in the number of haustoria per colony in the first steps of the infection. The resistance of the line BPL-484 is detected mainly in adult plants and is histologically observed as a decreased CS in the last phases of the colony development and a decreased sporulation.

The early response to infection of the hypersensitive lines was very similar to that of BPL-261, with a high early abortion of the colonies and with limited haustorium formation that was not associated with necrosis. This suggested that, besides the late hypersensitivity, in some lines (V-300, V-1271, and 2N34) there are additional mechanisms hampering haustorium development, similar to those of BPL-261. Thus, their resistance might be a combination of several mechanisms of resistance, similar to the resistance in flax to the flax rust $(M$. lini), where the hypersensitivity was also associated with quantitative resistance (13). This also can be confirmed by the negative correlation between LP and the percentage of colonies associated to host cells necrosis. However, in the line V-1273, it appears that the operating resistance is mainly due to hypersensitive mechanisms, as can be deduced from the low early abortion of the colonies in adult plants. The genetic basis of the hypersensitive resistance is under study but preliminary evidence suggests that it is monogenically inherited.

\section{ACKNOWLEDGMENTS}

We thank Projects 1FD97-0393 and INIA SC. 97-005-C2-1 for financial support and R. E. Niks for critical reading of the manuscript.

\section{LITERATURE CITED}

1. Bernier, C. C., and Conner, R. L. 1982. Breeding for resistance to faba bean rust. Pages 251-257 in: Faba Bean Improvement. G. Hawtin and C. Webb, eds. Martinus-Nijhoff Publishing, Dordrecht, The Netherlands.

2. Bhalla, M. K., and Bernier, C. C. 1984. Evaluation of the components of rate-reducing resistance in Vicia faba to Uromyces viciae-fabae. (Abstr.) Phytopathology 74:819.

3. Conner, R. L., and Bernier, C. C. 1982. Inheritance of rust resistance in inbred lines of Vicia faba. Phytopathology 72:1555-1557.

4. Cook, M. 1980. Peanut leaf wettability and susceptibility to infection by Puccinia arachidis. Phytopathology 70:826-830.

5. Furgal-Wegrzycka, H., Tomaszewski, Z., and Gonerska, J. 1985. Assessment of the susceptibility of Polish and foreign varieties of horse beans (Vicia faba M.) to pathogenic fungi. Rev. Plant Pathol. 64:279.

6. Hart, H. 1929. Relation of stomatal behavior to stem rust resistance in wheat. J. Agric. Res. 39:929-948.

7. Heath, M. C. 1974. Light and electron microscope studies of the interactions of host and nonhost plants with cowpea rust-Uromyces phaseoli var. vignae. Physiol. Mol. Plant Pathol. 4:403-414.

8. Herath, I. H. M. H. B., Stoddard, F. L., and Marshall, D. R. 2001. Evaluating faba beans for rust resistance using detached leaves. Euphytica 117:47-57

9. Jacobs, A. S., Pretorius, Z. A., Kloppers, F. J., and Cox, T. S. 1996. Mechanisms associated with leaf rust resistance derived from Triticum monococcum. Phytopathology 86:588-595.

10. Jacobs, T., and Buurlage, M. B. 1990. Growth of wheat leaf rust colonies in susceptible and partially resistant spring wheats. Euphytica 45:71-80.

11. Khalil, S. A., Nassib, A. M., and Mohammed, H. A. 1985. Identification of some sources of resistance to diseases in faba beans II-Rust (Uromyces fabae). FABIS Newsl. 11:18-20.

12. Kochman, J. K., and Brown, J. F. 1975. Development of the stem and crown rust fungi on leaves, sheaths, and peduncles of oats. Phytopathology 65:1404-1408.

13. Kowalska, A., and Niks, R. E. 1999. Histology of quantitative resistance in flax to the flax rust fungus (Melampsora lini). Can. J. Plant Pathol. 21:354-360.

14. Liang, X. Y. 1986. Faba bean diseases in China. FABIS Newsl. 15:49-51.

15. McLean, R. J. 1979. Histological studies of resistance to soybean rust, Phakopsora pachyrhizi Syd. Aust. J. Agric. Res. 30:77-84.

16. McLean, R. J., and Byth, D. E. 1981. Histological studies of the prepenetration development and penetration of soybean by rust, Phakopsora pachyrhizi Syd. Aust. J. Agric. Res. 32:435-443.

17. Mendgen, K. 1978. Attachment of bean rust cell wall material to host and non-host plant tissue. Arch. Microbiol. 119:113-117.

18. Mmbaga, M. T., and Steadman, J. R. 1990. Adult plant rust resistance and leaf pubescence on dry beans. Annu. Rep. Bean Improv. Coop. 33:61-62.

19. Niks, R. E. 1986. Failure of haustorial development as a factor in slow growth and development of Puccinia hordei in partially resistant barley seedlings. Physiol. Mol. Plant Pathol. 28:309-322.

20. Niks, R. E. 1987. The importance of abortive stoma penetration in the partial resistance and nonhost reaction of adult barley and wheat plants to leaf rust fungi. Euphytica 36:725-731.

21. Pal, A. B., Brahmappa, Rawal, R. D., and Ullasa, B. A. 1980. Field resistance of pea germ plasm to powdery mildew (Erysiphe polygoni) and rust (Uromyces fabae). Plant Dis. 64:1085-1086.

22. Rashid, K. Y., and Bernier, C. C. 1986. The genetics of resistance in Vicia faba to two races of Uromyces viciae-fabae from Manitoba. Can. J. 
Plant Pathol. 8:317-322.

23. Rashid, K. Y., and Bernier, C. C. 1986. Selection for slow rusting in faba bean (Vicia faba L.) to Uromyces viciae-fabae. Crop Prot. 5:218-224.

24. Rashid, K. Y., and Bernier, C. C. 1991. The effect of rust on yield of faba bean cultivars and slow-rusting populations. Can. J. Plant Sci. 71:967972.

25. Rohringer, R., Kim, W. K., Samborski, D. J., and Howes, N. K. 1977. Calcofluor: An optical brightener for fluorescence microscopy of fungal plant parasites in leaves. Phytopathology 67:808-810.

26. Romig, R. W., and Caldwell, R. M. 1964. Stomatal exclusion of Puccinia recondita by wheat peduncles and sheaths. Phytopathology 54:214-218.

27. Rubiales, D., and Carver, T. L. W. 2000. Defence reactions of Hordeum chilense accessions to three formae speciales of cereal powdery mildew fungi. Can. J. Bot. 78:1561-1570.

28. Rubiales, D., Moreno, I., Moreno, M. T., and Sillero, J. C. 2001. Identification of partial resistance to chickpea rust (Uromyces ciceris-arietini). Pages 194-195 in: Proc. 4th Eur. Conf. Grain Legumes. AEP. Cracow, Poland.

29. Rubiales, D., and Niks, R. E. 1992. Low appressorium formation by rust fungi on Hordeum chilense lines. Phytopathology 82:1007-1012.

30. Rubiales, D., and Niks, R. E. 1995. Characterization of Lr34, a mayor gene conferring nonhypersensitive resistance to wheat leaf rust. Plant
Dis. 79:1208-1212.

31. Sillero, J. C., Moreno, M. T., and Rubiales, D. 2000. Identification and characterization of new sources of resistance to Uromyces viciae-fabae in a germplasm collection of Vicia faba. Plant Pathol. 49:389-395.

32. Stakman, E. C., Stewart, D. M., and Loegering, W. Q. 1962. Identification of physiologic races of Puccinia graminis var. tritici. Minn. Agric. Exp. Sci. J. Ser. Pap. 4691.

33. Stavely, J. R., Steadman, J. R., and McMillan, R. T. 1989. New pathogenic variability in Uromyces appendiculatus in North America. Plant Dis. 73:428-432.

34. Subrahmanyam, P., McDonald, D., Reddy, L. J., Nigam, S. N., and Smith, D. H. 1993. Origin and utilization of rust resistance in groundnut. Pages 147-158 in: Durability of Disease Resistance. T. Jacobs and J. E. Parlevliet, eds. Kluwer Academic Publishers, Dordrecht, the Netherlands.

35. Suksayretrup, K., Kirkham, M. B., and Young, H. C., Jr. 1982. Stomatal resistance of five cultivars of winter wheat infected with leaf rust (Puccinia recondita f. sp. tritici). Z. Acker- Pflanzenb. 151:118-127.

36. Wynn, W. K. 1976. Appressorial formation over stomates by bean rust: Response to a surface contact stimulus. Phytopathology 66:136-146.

37. Wynn, W. K., and Staples, R. C. 1981. Tropisms of fungi in host recognition. Pages 45-69 in: Plant Disease Control: Resistance and Susceptibility. R. C. Staples and G. H. Toenniessen, eds. Wiley-Interscience, New York. 